\title{
HAK CIPTA DAN EKSPLOITASI CIPTAAN LAGU DAERAH KERINCI: PERSPEKTIF PENCIPTA
}

\author{
M. Zulfa Aulia* dan Isran Idris \\ Fakultas Hukum Universitas Jambi \\ Jl. Raya Jambi - Ma. Bulian KM 15 Mendalo, Jambi, 36361 \\ mzulfaaulia@unja.ac.id
}

\begin{abstract}
Copyright law allows a creator to control and monopolize the exploitation of his own work in the form of announcements and reproduction. This article seeks to identify and explain, in the case of the creation, the Kerinci folk songs, with regards to the interpretation of the creator about the the copyright and the exploitation of a work. Originally an empirical legal research, this article applied analysis on primary data obtained from interviews with the creator of the Kerinci folk songs. It is demonstrated in the article that the copyright for the creator of the Kerinci folk songs is not merely about rights or economic exploitation. Rather it is about satisfaction, recognition, and contribution it provides within the community and the region. Therefore, despite the very limited economic earns that might be obtained, the creator can find his own pride and satisfaction.
\end{abstract}

Keywords: Copyright; The Kerinci Folk Song; Reward of Work; Exploitation of Work

\begin{abstract}
Abstrak
Hukum tentang hak cipta memungkinkan seorang pencipta untuk mengontrol dan memonopoli eksploitasi penggunaan ciptaannya dalam bentuk pengumuman dan perbanyakannya. Tujuan dari tulisan ini adalah untuk mengidentifikasi sekaligus menjelaskan, dalam hal ciptaan itu berupa lagu daerah dalam hal ini lagu daerah Kerinci, bagaimanakah pencipta memaknai hak cipta dan eksploitasi suatu ciptaan. Tulisan ini berasal dari penelitian hukum empiris, dengan analisis terutama pada data primer berupa hasil wawancara dengan pencipta lagu daerah Kerinci. Tulisan ini menunjukkan, hak cipta bagi pencipta lagu daerah Kerinci dipahami tidak selalu tentang hak dan eksploitasi ekonomi, melainkan lebih pada kepuasan, pengakuan, dan kontribusi yang diberikannya kepada masyarakat dan daerah. Karena itu, sekalipun sangat terbatas kalaupun ada keuntungan ekonomi yang diperoleh, pencipta mendapatkan kebanggaan tersendiri.
\end{abstract}

Kata Kunci: Hak Cipta; Lagu Daerah Kerinci; Penghargaan Suatu Karya; Eksploitasi Ciptaan

\section{A. Pendahuluan}

Tulisan ini membahas persoalan hak cipta dan eksploitasi ciptaan lagu daerah Kerinci dilihat dari perspektif penciptanya. Pembahasan ini didasari alasan bahwa hak cipta di satu sisi memungkinkan pencipta untuk mengeksploitasi ciptaannya termasuk pada ciptaan lagu, namun di sisi lain karya cipta tertentu seperti lagu daerah Kerinci memiliki segmen konsumen yang relatif terbatas. Dalam hal adanya peluang pencipta untuk mengeksploitasi suatu ciptaan namun juga dijumpai keterbatasan ruang dan peluang mengeksploitasinya itu, menarik untuk diidentifikasi, bagaimana kemudian pencipta lagu daerah, dalam hal ini daerah Kerinci, memaknai hak cipta sekaligus eksploitasi suatu ciptaan.

Adanya peluang pencipta untuk mengeksploitasi suatu ciptaan sebenarnya terkait dengan makna dan hakikat hak cipta 
itu sendiri. Hak cipta adalah hak pencipta untuk mengumumkan dan memperbanyak ciptaan yang dihasilkannya. Dengan mengumumkan, yang dimaksudkan di sini adalah kegiatan apa pun yang menjadikan suatu ciptaan dapat dibaca, didengar, atau diindera oleh orang lain; sedangkan dengan memperbanyak, yang dimaksudkan adalah kegiatan apa pun yang dapat menambah jumlah suatu ciptaan. Hak mengumumkan dan memperbanyak ciptaan ini dalam hak cipta dilekatkan sebagai hak yang dimiliki oleh pencipta, dan karenanya terbuka peluang eksploitasi suatu ciptaan oleh penciptanya.

Lagu, yang menjadi fokus pembahasan ciptaan dalam tulisan ini, merupakan salah satu ciptaan yang dilindungi. Tergolongnya lagu ke dalam ciptaan ini disebabkan lagu merupakan karya di bidang seni. Hak cipta sendiri adalah suatu bidang hak kekayaan intelektual (HKI) yang ditujukan untuk melindungi karya-karya di bidang ilmu pengetahuan, seni, dan sastra.

Sebagai sebuah ciptaan yang mendapatkan perlindungan hak cipta, maka penggunaan suatu lagu-dalam artian pengumuman dan perbanyakannya - hanya dapat dilakukan oleh atau melalui izin dari penciptanya. Orang lain tidak dapat atau dibolehkan untuk mengumumkan dan memperbanyak ciptaan (lagu) tersebut, terkecuali sudah mendapat izin dari penciptanya. Penggunaan ciptaan secara demikian, disebut sebagai penggunaan yang eksklusif; dan karenanya hak yang dipunyai pencipta untuk menggunakan ciptaannya disebut hak eksklusif (Aulia, 2007).

Oleh karena sifatnya yang eksklusif tersebut, maka penggunaan ciptaan jelas bisa memberikan keuntungan kepada penciptanya. Hal ini disebabkan karena pencipta adalah pihak yang menentukan kapan, oleh siapa, dan atas dasar apa suatu ciptaan dapat diumumkan dan diperbanyak. Dengan penggunaan ciptaan secara demikian, maka akan ada keuntungan ekonomis dan moral yang diperoleh oleh pencipta. Hak-hak yang berkaitan dengan keuntungan ekonomis disebut hak ekonomi, sedangkan hak-hak yang berkaitan dengan keuntungan secara moral disebut hak moral. Pada lagu, hak ekonomis yang didapat oleh pencipta misalnya dari royalti pengumuman dan perbanyakan lagu tersebut; sedangkan hak moralnya berkenaan dengan dilekatkannya nama pencipta pada lagu tersebut dan hak untuk mempertahankan (termasuk mengubah) lagu ciptaannya itu.

Sebagai orang atau pihak yang mengekspresikan atau menuangkan ide kreatifnya ke dalam lagu, atau dalam istilah teknisnya disebut komposer yaitu seseorang yang menggubah sebuah karya music (Atmadja, 2003), pencipta semestinya mendapatkan keuntungan dari setiap kegiatan pengumuman dan perbanyakan lagu yang diciptakannya. Bahkan, sekalipun yang menyanyikan lagu tersebut orang (artis) lain, pencipta masih tetap mendapatkan keuntungan, karena akan mendapatkan royalti dari setiap lagu yang dinyanyikan. Ditinjau dari perspektif kesejahteraan seseorang, keuntungan secara ekonomis yang didapat oleh pencipta dari lagu yang telah diciptakannya merupakan bagian dari upaya meningkatkan kesejahteraan penciptanya. Paling tidak, kesejahteraan yang didapat itu berupa kesejahteraan ekonomis, yaitu keuntungan secara ekonomis yang diperoleh oleh pencipta.

Keuntungan secara ekonomis dan moral yang didapat pencipta dari suatu lagu yang diciptakannya sebenarnya banyak ditemui, terutama pada lagu-lagu yang populer. Namun demikian, keuntungan baik secara ekonomis maupun moral tersebut agaknya kurang terdengar pada lagu-lagu daerah, terlebih pada daerah yang ketersebaran komunitasnya relatif terbatas. Kondisi semacam ini tampaknya disebabkan keuntungan ekonomis memang belum mendapatkan perhatian dari masyarakat lokal (Idris, 2007).

Salah satu lagu daerah yang tampaknya memiliki keterbatasan ruang dan peluang dalam eksploitasinya, ialah lagu daerah Kerinci. Kerinci sendiri adalah salah satu kabupaten yang terdapat di ujung barat 
Provinsi Jambi. Suku bangsa dari daerah ini, yaitu suku bangsa Kerinci, telah menyebar luas bahkan sampai terdapat kampung Kerinci di negara Malaysia. Secara administratif, Kerinci saat ini dibedakan antara Kabupaten Kerinci dan Kota Sungai Penuh, yang sebenarnya daerah yang secara sosiologis sama-sama dikenali sebagai Kerinci. Daerah Kerinci dikenali sebagai daerah yang memiliki obyek wisata alam yang indah, antara lain berupa gunung tertinggi di Sumatera dan danau, sehingga menjadi daya tarik wisatawan untuk mengunjunginya. Hal ini sebenarnya menunjukkan adanya potensi yang tinggi bagi dikenali dan digunakannya lagu daerah Kerinci. Namun demikian, karena Kerinci memang bukan daerah dan suku bangsa yang besar seperti Jawa misalnya, maka yang demikian itu tidak mengurangi keterbatasan ketersebaran lagu daerah Kerinci.

Berdasarkan alasan tersebut, menarik untuk diteliti dan diidentifikasi, dari sudut pandang pencipta lagu daerah yang segmen penggunaannya terbatas seperti lagu daerah Kerinci, bagaimana sebenarnya hak cipta dan eksploitasi suatu ciptaan dimaknai. Identifikasi demikian dimaksudkan untuk mendalami hukum berlangsung dan bergerak di masyarakat, yaitu bagaimana masyarakat memaknai konsep-konsep hukum yang sekalipun secara teks normatif sudah ada kejelasannya, yaitu tentang hak cipta dan eksploitasinya.

\section{B. Metode Penelitian}

Tulisan ini berasal dari penelitian hukum empiris, yang mengidentifikasi sekaligus menjelaskan pandangan pencipta lagu daerah Kerinci tentang hak cipta dan eksploitasi suatu ciptaan dikaitkan dengan norma hukum hak cipta. Penelitian ini terutama menggunakan data primer, yaitu data yang diperoleh dan diolah melalui wawancara mendalam dengan pencipta lagu daerah Kerinci, yaitu Zulhatmi Ismail. Zulhatmi merupakan salah satu dari sedikit, kalau bukan satu-satunya, pencipta lagu daerah Kerinci yang ciptaannya banyak direkam, diperdengarkan, dan dipertunjukkan dalam berbagai kegiatan, terutama yang berlangsung di daerah. Nanti pada bagian profil pencipta akan terlihat karya-karya lagu Kerinci yang telah diciptakannya. Karena itu hasil identifikasi dan penjelasan dalam tulisan ini diharapkan dapat mengungkapkan bagaimana pencipta lagu di daerah memaknai hak cipta dan eksploitasi suatu ciptaan.

\section{Hasil dan Pembahasan}

\section{Tentang Hak Cipta dan Eksploitasi Ciptaan}

Hak cipta, yang merupakan salah satu bidang hak kekayaan intelektual, adalah kekayaan immateriil, atau di dalam KUHPerdata disebut benda tidak berwujud. Menurut Pasal 499 KUHPerdata, yang dinamakan benda adalah "tiap-tiap barang dan tiap-tiap hak yang dapat dikuasai oleh hak milik". Dengan demikian, hak sebagai benda yang tidak berwujud (immateriil) dihadapkan atau diperlawankan dengan barang yang merupakan benda yang mempunyai wujud (materiil, konkrit).

Sebagai salah satu objek hukum, maka hak cipta yang merupakan bagian benda tidak berwujud diperlakukan sama dengan benda-benda yang berwujud atau konkrit. Keduanya, benda tidak berwujud (hak) dan berwujud (barang), menurut KUHPerdata sama-sama dapat dikuasai dengan hak milik. Kalau barang semisal tanah atau kendaraan dapat beralih dan dialihkan, maka hak (termasuk hak cipta) juga demikian, dapat beralih dan dialihkan. Baik tanah maupun hak cipta, sama-sama dapat dijual, disewakan, dan juga diwariskan. Bahkan hak cipta memiliki keunggulan yang lain. Kalau benda berupa barang hanya bisa dijual sekali, maka hak cipta dapat dilisensikan berkali-kali, tergantung pada jenis lisensinya. Kalau barang mempunyai batasan jumlah, maka hak cipta tidak akan habis-habisnya selama manusia berkarya, sebab hak cipta merupakan hasil olah pikir manusia. 
Hak cipta adalah hak eksklusif yang dipunyai seseorang, dan karenanya hanya pencipta dan pemegang hak cipta yang boleh menggunakannya. Orang atau pihak lain baru dapat menggunakannya juga setelah mendapatkan izin dari penciptanya. Menurut Pasal 1 angka 1 UU No. 28 Tahun 2014 tentang Hak Cipta, "hak cipta adalah hak eksklusif pencipta yang muncul secara otomatis berdasarkan prinsip deklaratif setelah suatu ciptaan diwujudkan dalam bentuk nyata tanpa mengurangi pembatasan sesuai dengan ketentuan peraturan perundang-undangan".

Pada hak cipta, yang termasuk obyek perlindungannya adalah semua karya di bidang ilmu pengetahuan, seni, atau sastra yang menunjukkan keaslian atau orisinalitasnya. Namun demikian, UU Hak Cipta membatasi karya-karya apa saja yang termasuk dalam bidang ilmu pengetahuan, seni dan sastra. Menurut Pasal 40 UU Hak Cipta, yang termasuk sebagai ciptaan antara lain adalah buku, program komputer, pamflet, perwajahan (lay out) karya tulis yang diterbitkan, dan semua hasil karya tulis lain; ceramah, kuliah, pidato, dan ciptaan lain yang sejenis dengan itu; alat peraga yang dibuat untuk kepentingan pendidikan dan ilmu pengetahuan; lagu atau musik dengan atau tanpa teks; drama atau drama musikal, tari, koreografi, pewayangan, dan pantomim; seni rupa dalam segala bentuk seperti seni lukis, gambar, seni ukir, seni kaligrafi, seni pahat, seni patung, kolase, dan seni terapan; arsitektur; peta; seni batik; fotografi; sinematografi; terjemahan, tafsir, saduran, bunga rampai, database, dan karya lain dari hasil pengalihwujudan.

Pada dasarnya, perlindungan hak cipta di Indonesia menginduk pada perlindungan hak cipta yang berlaku secara internasional. Hal ini dikarenakan Indonesia telah meratifikasi Trade Related Aspects of Intellectual Property Rights (TRIPs), yang merupakan perjanjian internasional yang berkenaan dengan aspek-aspek dagang yang terkait dengan HKI. TRIPs sendiri adalah salah satu lampiran dari perjanjian pembentukan Organisasi Perdagangan
Dunia (Agreement Establishing the Word Trade Organization). Perjanjian Organisasi Perdagangan Dunia ini diratifikasi Indonesia melalui UU No. 7 Tahun 1994. Ia menjadi standar minimal dalam perlindungan HKI termasuk hak cipta suatu negara (Sutrisno, 1999; Kariodimedjo, 2010) . Karena itu, secara politik hukum tidak bisa dihindari pembentukan dan pemberlakuan hak cipta dan bidang HKI lainnya lebih mencerminkan kepentingan asing (Riswandi, 2004; Aulia, 2015), sebagai bagian dari upaya harmonisasi hukum nasional terhadap perkembangan hukum global (Sulistyawan, 2019).

Perlindungan pada hak cipta, dan juga bidang hak kekayaan intelektual lainnya, menjadi diperlukan karena untuk menjamin kelanjutan perkembangan hak milik intelektual dan menghindari kompetisi yang tidak layak (unfair competition). Kalau perlindungan terhadap orang-orang yang telah membuat karya kreatif tidak diberikan, maka setiap orang akan dapat meniru dan membuat copy secara bebas serta mereproduksi tanpa batas. Hal ini berarti tidak ada insentif untuk memperkembangkan kreasi-kreasi baru, dan menjadi jelas pula bahwa perkembangan dan pembangunan di bidang kesenian, industri, dan ilmu pengetahuan akan terganggu (Gautama, 1995).

Semakin banyak, semakin beragam, dan semakin berkualitas kekayaan intelektual yang diciptakan seorang pencipta, di satu pihak akan memberi nilai tambah terhadap martabat (dignity) dan keuntungankeuntungan materiil atau ekonomi seorang pencipta yang melahirkan suatu kekayaan intelektual bersangkutan. Di lain pihak, hal demikian akan mencerdaskan kehidupan bangsa pada umumnya (Damian, 2005).

\section{Profil Pencipta dan Karyanya}

Pencipta lagu daerah Kerinci yang menjadi subyek penelitian ini adalah Zulhatmi Ismail. Ia dilahirkan di Kerinci pada 4 November 1947. Lahir dan besar di Kerinci, ia kemudian pernah berdomisili di Bangko, dan sudah sejak lama sampai saat 
ini di Kota Jambi (Jalan Sunan Giri Lorong Angkasa).

Zulhatmi Ismail merupakan sedikit, kalau bukan satu-satunya, pencipta lagu Kerinci yang hasil ciptaannya relatif banyak direkam, diperdengarkan, dan dipertunjukkan dalam berbagai kegiatan, terutama yang berlangsung di daerah. Ia mengaku, menciptakan lagu merupakan kesenangannya. Dengan menciptakan lagu, ia mendapatkan kepuasaan secara lahiriah dan batiniah begitu lagu tersebut tercipta.

Zulhatmi mulai menciptakan lagu pada 1968. Lagu pertama yang diciptakannya pada saat itu adalah Hujon rinteak. Sebagai karya pertama, ia merasakan kepuasan tersendiri, dan itu masih terasa sampai sekarang. Semenjak saat itu sampai sekarang, tidak kurang dari 80-an lagu yang diciptakannya. Tidak semua hasil ciptaan tersebut didokumentasikan, dan karenanya jumlahnya tidak dapat disebutkan secara pasti. Seingatnya, jumlah lagu tersebut berada pada kisaran 80 namun tidak sampai 100.

Dari sejumlah lagu yang diciptakannya, yang pernah dilakukan perekaman mencapai kisaran 20-30 lagu. Di sini ia juga hanya menyebutkan kisaran jumlah, disebabkan pada sebagian lagu yang direkam, terutama yang berlangsung pada 1968 hingga 1980an, tidak tersedia lagi dokumentasinya. Hal ini bisa dimaklumi, karena perekaman pada saat itu membutuhkan biaya yang mahal dan karenanya dokumentasi yang dipunyai juga tidak banyak, sehingga banyak pula yang tidak tersedia lagi saat ini.

Dari berbagai lagu yang diciptakan dan dilakukan perekaman, Zulhatmi menyebutkan, lagu yang paling populer adalah Hujon rinteak, Delidau, dan Ujun pasir. Dari lagu yang populer ini, tentu bagi Zulhatmi menyimpan kenangan dan kebanggaan tersendiri, terutama Hujon rinteak yang merupakan lagu pertama yang diciptakannya.

Sebagian besar lagu yang diciptakan Zulhatmi dan kemudian direkam, dinyanyikan oleh artis-artis lokal, terutama Monalisa dan Jasminar. Hal ini perlu diungkapkan, karena sebagian lagu daerah, termasuk di Jambi, ternyata juga dibawakan dan dipopulerkan oleh artis nasional, semisal Ike Nurjanah yang turut mendendangkan lagu Negeri Jambi.

\section{Model Eksploitasi Lagu Daerah Kerinci}

Pada bagian ini ditelaah, bagaimana eksploitasi suatu lagu yang diciptakan itu berlangsung: dimulai dari mana dan berakhir pada tahap apa. Jadi, semenjak diciptakan, bagaimana proses yang berlangsung sehingga dibawakan oleh artis, dilakukan perekaman, dan kemudian dikonsumsi oleh masyarakat.

Zulhatmi Ismail menuturkan, perekaman lagu hasil ciptaannya ada yang menggunakan kaset tape dan ada juga yang berbentuk CD (compact disk). Untuk perekaman dalam bentuk kaset tape dilakukan di Kota Padang, Sumatera Barat; sedangkan untuk perekaman dalam bentuk CD dilakukan di Jakarta.

Untuk sampai pada perekaman, pencipta terlebih dahulu memilih artis yang membawakannya dan pengiring yang memainkan musiknya. Setelahnya, pencipta bersama sponsor mencari produser rekaman. Di sini produser rekaman dibayar sejak awal untuk merekam lagu tertentu. Jadi, berbeda dengan lagu-lagu yang menjadi konsumsi nasional dan global, dimana produser rekaman suara yang membiayai dan memfasilitasi perekaman, maka pada lagu daerah (Kerinci) ini pencipta yang membayar produser rekaman suara tersebut untuk merekam apa yang dipesannya.

Kondisi seperti itu, dimana pencipta mencari sponsor dan produser rekaman sendiri, dengan mudah dapat dimaklumi. Sebab, dengan lagu yang belum tentu banyak digunakan (dikonsumsi), terlebih lagu daerah yang penggunaannya terbatas, produser rekaman tentu sulit ataupun kalau bisa memerlukan waktu yang lama sehingga biaya produksi yang dikeluarkan dapat tertutupi oleh keuntungan dari penjualan kaset atau CD. Oleh karenanya, satu-satunya cara yang dapat dilakukan kalau hendak 
direkam, pencipta mesti mencari sponsor terlebih dahulu untuk selanjutnya produser rekaman suara dibayar sejak awal.

Dengan demikian, perekaman lagu dengan cara membayar terlebih dahulu produser rekamannya merupakan hal yang biasa terjadi, terlebih pada lagu-lagu yang dikonsumsi secara terbatas, seperti lagu daerah Kerinci. Hal ini berarti pencipta diharuskan mengeluarkan biaya pribadi yang tidak kecil sehingga lagu yang diciptakannya dapat direkam, terkecuali ada sponsor yang membiayainya.

Dengan model perekaman secara demikian, maka keuntungan yang didapat dari penjualan kaset dan CD serta keuntungan lainnya yang didapat dari penggunaan lagu yang diciptakannya, sepenuhnya menjadi hak pencipta (beserta sponsor, jika perekamannya menggunakan sponsor). Hal ini berarti pembagian keuntungan tidak melibatkan produser rekaman suara sama sekali. Pada umumnya, menurut Zulhatmi Ismal, pembagian keuntungan dilakukan antara pencipta dan sponsor. Di antara kedua pihak tersebut, sponsor mendapatkan keuntungan sebesar 70 persen dan pencipta selebihnya (30 persen). Besarnya keuntungan yang didapat sponsor disebabkan karena biaya-biaya yang selama ini dikeluarkan untuk proses perekaman menggunakan biaya sponsor. Selain itu, risiko secara ekonomis, yaitu dari biaya yang dikeluarkan dan kemungkinan didapat, juga lebih besar ditanggung oleh sponsor.

Model produksi dan perekaman lagu daerah semacam itu berbeda dengan produksi dan perekaman lagu pada umumnya yang tidak lokal. Pada umumnya, produser rekaman, sebagai penerima lisensi dalam pembuatan rekaman dan eksploitasinya (Sardjono, 2010; Anjelfa, 2015), justru menjadi pihak yang sangat menentukan produksi suatu lagu. Mereka, karena memiliki bargaining position yang dominan, bisa mendikte kemauannya melalui kontrak, besaran honor, dan waktu pembayarannya. Hal ini bisa terjadi karena memang produksi sampai perekaman ini umumnya sepenuhnya dibiayai oleh produser rekaman (Atmadja, 2003), sesuatu yang tidak terjadi dalam produksi dan perekaman lagu daerah dalam hal ini Kerinci, yang justru sepenuhnya dibiayai oleh pencipta atau sponsor.

Sebenarnya masih ada pihak lain yang juga terlibat dalam perekaman suara, yaitu artis dan pemain musik pengiring. Namun demikian, mereka tidak dilibatkan dalam pembagian keuntungan dari penjualan kaset dan $\mathrm{CD}$, disebabkan mereka ini merupakan pihak yang berada di bawah pengelolaan dan tanggung jawab pencipta. Oleh pencipta sebagai penanggung jawab, artis dan pengiring musik ini sudah dibayar sejak awal. Dengan demikian, untuk keuntungan dari penjualan kaset tape dan $C D$, keuntungan dibagi berdua oleh sponsor dan pencipta. Kalaupun ada bagian untuk artis dan pengiring musik, hal itu merupakan bonus saja.

Bagaimana dengan keuntungan yang didapat dari pertujukan artis ketika membawakan lagu tersebut, apakah ada pembagian keuntungan antara pencipta dan artis serta juga pengiring musik? Zulhatmi menjelaskan, segala keuntungan yang didapat melalui pertunjukan lagu oleh artis, sepenuhnya menjadi haknya artis. Pencipta di sini tidak mendapatkan bagian, sebab menurutnya yang terlibat dalam pertunjukan tersebut adalah artis (dan mungkin juga pengiring musik).

Berdasarkan ketentuan dalam UU Hak Cipta, pencipta yang karya ciptanya dibawakan oleh orang atau pihak lain (termasuk artis) sebetulnya tetap mendapatkan bagian dari keuntungan yang didapat karena ditampilkannya lagu tersebut. Dalam UU Hak Cipta, hak cipta disebutkan bukan saja meliputi hak memperbanyak (kalau dalam lagu misalkan berupa hak membuat rekamannya), tetapi juga meliputi hak untuk mengumumkannya (termasuk ke dalamnya membacakan atau menampilkan suatu ciptaan di depan publik). Hal ini berarti, UU Hak Cipta menjamin kepentingan pencipta untuk mengeksploitasi karya ciptanya. 
Ketentuan seperti itu sebenarnya disadari oleh Zulhatmi. Namun demikian, menurutnya, ia sudah sangat senang begitu mengetahui lagunya dibawakan oleh artis dalam berbaga kegiatan; termasuk ketika suatu kali diketahuinya ada artis dari Bandung yang membawakannya untuk ditampilkan di Bandung. Bagi Zulhatmi, dengan ditampilkannya lagu ciptaannya oleh artis dalam berbagai kegiatan, justru akan membuat lagunya menjadi lebih dikenal. Zulhatmi menegaskan, "lagu kalau tidak dinyanyikan orang lain menjadi tidak populer, sehingga semakin banyak (sering, penulis) dinyanyikan akan semakin baik".

Temuan eksploitasi ciptaan lagu daerah Kerinci dari perspektif pencipta ini menunjukkan bahwa penggunaan ciptaan oleh orang lain, dalam hal ini melalui kegiatan pengumuman, tidaklah dianggap sebagai sebuah pelanggaran hak cipta. Adanya pihak lain yang membawakan ciptaannya, misalnya menampilkannya di dalam acara-acara dan di hadapan publik, malah dianggapnya sebagai sebuah kebanggaan dan justru diapresiasinya. Sebab, kegiatan tersebut justru akan mendorong lagu yang telah diciptakannya untuk dikenali publik.

Sebagai pencipta, Zulhatmi tidak pernah mempersoalkan penggunaan lagu ciptaannya oleh pihak lain. Hal ini tentu agak menyulitkan jika ditinjau dari hukum hak cipta, kapan sebenarnya suatu penggunaan ciptaan dari persepktif pencipta akan dianggap sebagai sebuah pelanggaran, dan apa sebenarnya batasannya. Namun, dengan penegasannya bahwa "lagu kalau tidak dinyanyikan orang lain menjadi tidak populer, sehingga semakin banyak dinyanyikan akan semakin baik", memperlihatkan sikapnya yang tidak mengategorikan penggunaan ciptaan oleh pihak lain sekalipun tanpa seizinnya sebagai sebuah pelanggaran akan hak-haknya, sehingga dengan demikian tidak ada pula batasan mana yang pelanggaran dan mana yang bukan.

Dari segi normatif UU Hak Cipta, hal demikian dapat dijelaskan bahwa hak eksklusif penggunaan suatu ciptaan sesungguhnya akan sangat bergantung pada sikap dari penciptanya sebagai pemilik hak. UU Hak Cipta dalam hal ini hanya menjadi panduan dan pedoman bahwa penggunaan suatu ciptaan dalam bentuk pengumuman dan perbanyakan merupakan hak eksklusif dari penciptanya, yang muncul secara otomatis begitu suatu ciptaan selesai dikerjakan. Oleh karena hak tersebut eksklusif, maka penggunaan oleh pihak lain secara normatif menurut UU Hak Cipta harus seizin dari penciptanya. Namun demikian, sebagai bagian dari hak privat atau keperdataan yang bersifat personal (personal right) (Amrani, 2018; Kurnianingrum, 2015), implementasi hak eksklusif ini sesungguhnya sangat bergantung pada pemilik hak, yang sangat privat. Dalam hal pemilik hak mempersoalkan penggunaan suatu ciptaan oleh orang lain tanpa seizinnya, maka yang demikian itu dapat dikategorikan sebagai pelanggaran, dengan catatan penggunaannya tidak dalam kategori yang wajar dan diperbolehkan misalnya untuk pendidikan, penelitian, dan pembuktian. Demikian pula, jika pemilik hak ternyata tidak mempersoalkan, maka penggunaan oleh orang lain sekalipun tanpa seizinnya tidak pula berkategori sebagai pelanggaran.

Terlepas dari kategorisasinya sebagai hak privat atau keperdataan sehingga implementasinya dalam artian penyikapannya terhadap penggunaan oleh pihak lain sangat bergantung pada masingmasing pencipta, temuan dalam tulisan ini secara sosiologis setidaknya membuka perspektif lain bagaimana pencipta memaknai dan memperlakukan suatu ciptaan. Pada suatu ciptaan seni dalam bentuk lagu daerah yang penggunaannya relatif terbatas, pencipta memandang lagu yang telah diciptakannya sebagai sebuah karya yang penggunaannya tidak eksklusif miliknya. Dengan demikian, siapa pun menjadi terbuka untuk terlibat dalam penggunaannya, karena justru dinilainya akan mendorong lebih dikenalinya ciptaannya. 


\section{Keuntungan Ekonomis Pencipta dari Penggunaan Ciptaannya}

Dengan keuntungan ekonomis yang didapat relatif terbatas pada penjualan kaset tape dan $\mathrm{CD}$, pencipta dari sisi ekonomis sebenarnya tidak mendapatkan keuntungan yang signifikan dari eksploitasi karya ciptanya. Terlebih lagi hasil penjualan tersebut sebenarnya sangat terbatas, mengingat konsumennya juga relatif terbatas pada daerah saja. Keterbatasan keuntungan ekonomis yang didapat dari eksploitasi suatu ciptaan pada lagu daerah Kerinci semakin terlihat dari keuntungan yang didapat dari digunakannya atau ditampilkannya lagu tersebut pada berbagai acara, sebab keuntungan tersebut pada kenyataannya ternyata menjadi haknya artis.

Oleh sebab itu, secara ekonomis sebetulnya tidak banyak keuntungan finansial yang didapat pencipta dari eksploitasi lagu ciptaannya. Apakah hal demikian lalu berarti bahwa eksploitasi suatu ciptaan tidak turut memengaruhi kesejahteraan penciptanya, tentu perlu ditelaah lebih lanjut. Apabila kesejahteraan seseorang diukur dari keuntungan secara finansial dan ekonomis, maka kesejahteraan pada pencipta lagu Kerinci seperti yang dirasakan Zulhatmi Ismail memang relatif tidak terpengaruh oleh eksploitasi lagu ciptaannya. Namun demikian, jika kesejahteraan yang dimaksud tidak terbatas pada soal ekonomis, tentu berbeda jawabannya.

Sebagai pencipta, Zulhatmi tidak memperhitungkan keuntungan finansial dan ekonomis sebesar berapa yang diperoleh dari menciptakan lagu. Baginya, yang terpenting adalah lagu telah diciptakannya. Hal ini menunjukkan bahwa tujuan utama dari penciptaan lagu daerah Kerinci oleh Zulhatmi bukanlah dimaksudkan untuk mendapatkan keuntungan ekonomis, melainkan kepuasan telah menghasilkan suatu ciptaan. Karena itu, karakter hak moral pencipta, yaitu integritas (dignity) dan identitas (paternity) (Hapsari, 2012), sangat terlihat dalam maksud penciptaan lagu daerah Kerinci ini ketimbang hak ekonomisnya. Dalam konteks hak moral ini, maka karya cipta merupakan ekspresi atau pengejewantahan dari pribadi pencipta (Soelistyo, 2011).

Sejak awal Zulhatmi menyadari, tidak mungkin mengandalkan pendapatan ekonomi dari menciptakan lagu daerah. Sebab, menurutnya, lagu daerah pada umumnya dipasarkan dan dipakai secara terbatas. Oleh karenanya, keuntungan dari penjualan kaset dan penampilan lagu dari berbagai kegiatan tentu terbatas pula. Alihalih untuk mendapatkan keuntungan ekonomis, berbagai biaya bahkan harus dikeluarkan lebih dahulu. Itulah sebabnya, untuk sumber pendapatan ekonomi, ia harus mengandalkan sumber pendapatan yang lain.

Dengan demikian, bagi Zulhatmi, yang lebih penting dari penciptaan lagu daerah ini adalah berkembangnya kebudayaan daerah yang antara lain tercermin pada perkembangan kesenian daerah. Paling tidak, dengan ikut mengembangkan kebudayaan daerah, ia turut berkontribusi dan berperan serta dalam pembangunan daerah.

Dengan tujuan penciptaan lagu daerah seperti itu, daripada mengharap keuntungan ekonomis yang diperoleh dari perbanyakan dan pengumuman lagu yang diciptakannya, Zulhatmi justru merasa bangga bisa mengembangkan lagu daerah Kerinci. Penerimaan lagu tersebut oleh masyarakat dianggap sebagai penghargaan tertinggi atas kinerjanya dalam menghasilkan suatu lagu. Di antara bentuk penerimaan masyarakat tersebut tercermin dari digunakannya lagu yang diciptakannya dalam berbagai acara adat termasuk perkawinan, dan juga dalam berbagai festival lagu daerah di Jambi.

Uraian barusan yang menunjukkan tidak banyak keuntungan ekonomis yang didapat dari menciptakan lagu daerah, sekalipun lagu-lagu yang diciptakan Zulhatmi termasuk lagu daerah Kerinci yang banyak dipakai dan ditampilkan, mengindikasikan bahwa eksploitasi ciptaan lagu daerah tidak berpengaruh besar bagi kesejahteraan pencipta. Hal demikian mudah dipahami 
mengingat keterbatasan pemakaian lagu daerah. Lagu-lagu daerah yang banyak dipakai dan ditampilkan dalam berbagai kegiatan nasional dan internasional pada umumnya lagu yang berasal dari etnis yang besar, semisal Jawa, Sunda, dan Minang.

Namun demikian, karena tujuan awal menciptakan lagu daerah adalah untuk mengembangkan kesenian yang ada di daerah, maka keterbatasan dari pendapatan secara ekonomis tersebut tidak berarti bahwa kesejahteraan pencipta tidak terpenuhi. Kepuasan batin karena turut mengembangkan kesenian daerah dan turut berpartisipasi dalam pembangunan daerah dapat dianggap sebagai bagian dari meningkatnya kesejahteraan pencipta secara batiniah. Tolok ukur kesejahteraan seseorang (pencipta) yang tidak sekadar bertumpu pada hal-hal yang sifatnya lahiriah namun juga batiniah ini sejalan dengan upaya pencarian metode pengukuran kesejahteraan yang semakin komprehensif, yang meliputi hal-hal yang sifatnya material dan non-material sekaligus (Rama, 2015).

Dalam studi hak cipta, pemaknaan kesejahteraan yang demikian itu menegaskan bahwa hak cipta itu tidak melulu soal reproduksi suatu karya, tetapi juga integritas dan reputasi pencipta (Sardjono, 2010). Dari perspektif sejarah hak cipta, hal ini juga sejalan dengan perkembangan awal hak cipta bahwa karya atau ciptaan tidak selalu berkenaan dengan kekayaan atau properti, yang sebenarnya baru mulai berkembang dan dikembangkan pada abad 18, tetapi juga hak-hak pengarang yang lebih berkaitan dengan integritas dan reputasinya (Stern, 2012).

Hanya saja memang, bagaimanapun juga kesejahteraan secara lahiriah, yang tercermin dari meningkatnya keuntungan ekonomis, tetap diperlukan. Oleh karenanya, berbagai alternatif lain perlu diupayakan sehingga pencipta menjadi semakin merasa dihargai dari kinerjanya selama ini mengembangkan kesenian daerah, sehingga bisa menjadi insentif untuk terus melanjutkan penciptaan karya-karya berikutnya yang berguna bagi pengembangan budaya dan kesenian daerah.

Perlindungan hak cipta sendiri sebenarnya dimaksudkan agar pencipta mendapatkan penghargaan (reward) dari kinerjanya yang menghasilkan suatu ciptaan. Penghargaan tersebut tercermin dari adanya jaminan perlindungan hukum bahwa penggunaan suatu ciptaan dalam bentuk perbanyakan dan pengumuman hanya dapat dilakukan oleh pencipta. Penggunaan ciptaan tersebut oleh pihak lain di luar pencipta hanya dimungkinkan apabila penggunaan tersebut untuk kepentingan pendidikan, penelitian, dan pembuktian. Penggunaan suatu ciptaan untuk kepentingan komersial tidak dimungkinkan, terkecuali dengan izin terlebih dahulu dari penciptanya. Hak penggunaan ciptaan semacam ini disebut dengan hak eksklusif dalam menggunakan suatu ciptaan.

Adanya penghargaan (reward) kepada pencipta berupa hak eksklusif seperti itu penting agar pencipta dapat terus melanjutkan menciptakan karya-karya berikutnya. Dengan demikian jaminan perlindungan berupa hak eksklusif tersebut menjadi insentif bagi pencipta sehingga dapat terpacu untuk menghasilkan karyakarya selanjutnya. Lebih dari itu, bagi masyarakat, hal demikian diharapkan mampu mendorong untuk lebih kreatif dan inovatif dalam menghasilkan suatu karya (Roisah, 2012).

Berkenaan dengan ciptaan lagu daerah seperti Kerinci, disebabkan tidak bisa diandalkan keuntungan ekonomis yang didapat dari penggunaan lagu tersebut, maka alternatif-alternatif lain yang tidak berasal dari perbanyakan ataupun pengumuman menjadi diperlukan. Beberapa alternatif yang ditawarkan dari penelitian ini adalah, adanya insentif dari pemerintah daerah, penggunaan lagu dalam berbagai acara seremonial daerah, menyelenggarakan festival lagu-lagu daerah, dan memberikan anugerah daerah di bidang kesenian.

Pertama, insentif oleh pemerintah daerah. Hal ini penting karena adanya insentif dapat membantu biaya produksi 
suatu lagu. Meskipun insentif yang diberikan barangkali tidak bisa menutupi biaya produksi, insentif yang diberikan akan dianggap oleh pencipta sebagai dukungan secara nyata dari pemernitah daerah dalam pengembangan kesenian daerah. Untuk menghindari kemungkinan penyalahgunaan insentif ini, maka insentif sebaiknya diberikan pada saat lagu daerah sudah diproduksi. Jadi, lagu itu harus ada terlebih dahulu, dibuktikan dalam bentuk kopi kaset tape dan $\mathrm{CD}$, baru selanjutnya dapat diberikan insentif.

Kedua, penggunaan lagu daerah dalam berbagai acara seremonial daerah. Selama ini daerah seringkali menyelenggarakan acara-acara seremonial, semisal pada perayaan ulang tahun daerah. Pada acara seperti ini, ditampilkannya lagu daerah akan menjadi kebanggaan bagi pencipta dan artisnya. Di Kerinci, potensi penggunaan lagu seperti ini sangat besar, mengingat pemerintah kabupaten punya kegiatan rutin tahunan untuk mempromosikan wisata yang ada di sana, yaitu melalui Festival Danau Kerinci. Pada festival semacam ini, tidak sedikit dari pengunjung yang datang berasal dari berbagai daerah di luar Provinsi Jambi sekalipun. Oleh karenanya, ditampilkannya lagu daerah Kerinci pada acara semacam itu berguna bagi promosi kesenian yang ada di daerah.

Penggunaan lagu daerah dalam berbagai acara seremonial daerah ini relevan karena, sebagaimana sudah dibahas sebelumnya dalam artikel ini, pencipta sendiri mendapatkan kepuasan batin manakala lagu ciptaannya dapat turut serta mengembangkan kesenian daerah dan pembangunan daerah. Dalam konteks perlindungan hak cipta, penggunaan lagu daerah dalam berbagai acara seremonial daerah justru menjadi sebuah penghargaan bagi pencipta, dan hal ini sejalan dengan doktrin moral hak cipta agar menghargai karya orang lain.

Namun demikian, karena tujuan awal menciptakan lagu daerah adalah untuk mengembangkan kesenian yang ada di daerah, maka keterbatasan dari pendapatan secara ekonomis tersebut tidak berarti bahwa kesejahteraan pencipta tidak terpenuhi. Kepuasan batin karena turut mengembangkan kesenian daerah dan turut berpartisipasi dalam pembangunan daerah dapat dianggap sebagai bagian dari meningkatnya kesejahteraan pencipta secara batiniah.

Ketiga, menyelenggarakan festival lagu daerah. Festival tersebut dapat berupa lomba cipta lagu ataupun lomba membawakan lagu. Selama ini festival lagu daerah sebenarnya juga diselenggarakan. Namun demikian, untuk memacu perkembangan kesenian daerah, festival sebaiknya diselenggarakan secara rutin.

Keempat, pemberian anugerah di bidang kesenian (termasuk lagu) oleh pemerintah daerah. Anugerah dapat diberikan, misalnya pada saat hari ulang tahun kabupaten/kota. Anugerah yang diberikan tidak usah dibatasi pada bidang kesenian, tetapi juga meliputi, misalkan anugerah di bidang pendidikan, anugerah di bidang olah raga, anugerah di bidang pertanian, dan sebagainya, termasuk di bidang kesenian. Pada bidang kesenian ini, bisa jadi yang mendapatkannya adalah pencipta lagu. Apabila hal ini terwujud, maka pencipta lagu (jika dia yang mendapatkan anugerah di bidang kesenian) jelas merasa dihargai dan didukung oleh pemerintah dalam mengembangkan lagu daerah.

Alternatif-alternatif seperti yang dibahas dalam penelitian ini perlu dicoba diupayakan, mengingat keuntungan secara ekonomis yang didapat pencipta dari menciptakan lagu daerah tidaklah banyak. Dengan mencoba mengupayakan alternatifalternatif tersebut, yang sifatnya mendukung dan menghargai atas kinerja pencipta, maka pencipta diharapkan semakin termotivasi dalam menciptakan lagu-lagu daerah. Penghargaan, penghidupan yang layak, dan kemandirian di bidang ekonomi, pada dasarnya adalah sifat dasar manusia yang diharapkan dapat dipenuhi melalui perlindungan HKI (Antariksa, 2012). Dalam kaitan dengan lagu daerah, hal demikian 
menjadi penting bukan hanya dalam kepentingan privat penciptanya, melainkan juga dalam upaya mengembangkan kesenian dan potensi yang terdapat di daerah.

\section{Simpulan dan Saran}

Eksploitasi lagu daerah Kerinci oleh pencipta dilakukan dalam bentuk perbanyakan lagu tersebut melalui kaset tape dan CD (compact disk). Dalam perbanyakan lagu ini, pihak yang terlibat adalah pencipta, produser rekaman suara, dan seringkali juga melibatkan sponsor. Namun demikian, karena produser rekaman suara merupakan pihak yang dibayar untuk merekam lagu, sehingga eksploitasi perbanyakan lagu sebenarnya hanya melibatkan pencipta dan sponsor. Meskipun eksploitasi dapat juga dilakukan dalam bentuk pengumuman (penyiaran, penampilan) lagu, hal ini tidaklah dilakukan. Sebab, eksploitasi dalam penyiaran dan penampilan tersebut, menurut pencipta, lebih banyak melibatkan artis ketimbang pencipta.

Eksploitasi lagu daerah Kerinci oleh pencipta selama ini relatif tidak berpengaruh besar terhadap keuntungan ekonomis yang didapat. Selain keterbatasan pengguna atau pengaksesnya, hal ini juga disebabkan tujuan penciptaan lagu tersebut sejak awal memang lebih dimaksudkan untuk mengembangkan kesenian daerah dan memberi kontribusi pada pembangunan daerah. Dengan demikian, dari sisi pendapatan ekonomi, eksploitasi dari suatu lagu daerah (Kerinci) relatif tidak dapat diharapkan. Dari segi hak cipta yang membedakan hak ekonomi dan hak moral, temuan semacam ini menunjukkan bahwa hak cipta bagi pencipta lagu daerah Kerinci tidak selalu melulu soal hak dan eksploitasi ekonomi, melainkan lebih pada kepuasan, pengakuan, dan kontribusi yang diberikannya kepada masyarakat dan daerah. Karena itu, dimensi hak moral lebih terlihat dalam penciptaan lagu daerah Kerinci ketimbang hak ekonominya, yaitu berkenaan dengan integritas dan identitas penciptanya.
Agar eksploitasi lagu daerah berkorelasi dengan peningkatan kesejahteraan pencipta, sebagai saran, perlu diupayakan alternatif yang dapat mendukung pencipta dalam menciptakan lagu. Hal ini penting karena ciptaan lagu daerah bukan saja berkenaan dengan kepentingan privat penciptanya, melainkan juga erat kaitannya dengan pengembangan kesenian dan potensi daerah. Beberapa alternatif yang perlu dilakukan adalah, pemberian insentif, penggunaan lagu pada acara-acara seremonial yang diselenggarakan pemerintah daerah, penyelenggaraan festival lagu daerah, dan pemberian anugerah di bidang kesenian. Beberapa alternatif yang ditawarkan ini meliputi dimensi hak ekonomi sekaligus juga hak moral dari penciptanya.

\section{DAFTAR PUSTAKA}

Amrani, H. (2018). Urgensi Perubahan Delik Biasa Menjadi Delik Aduan dan Relevansinya terhadap Perlindungan dan Penegakan Hak Cipta. Undang: Jurnal Hukum, 1(2), 347-362. http://doi.org/10.22437/ujh.1.2.347-362

Anjelfa, R. (2015). Perlindungan Hukum atas Karya Hasil Rekaman Suara yang Dikonversi dalam Bentuk Compact Disk. Notarius, 8(2), 315-341. http://doi.org/10.14710/nts.v8i2.10268

Antariksa, B. (2012). Landasan Filosofis dan Sejarah Perkembangan Perlindungan Hak Kekayaan Intelektual: Relevansinya bagi Kepentingan Pembangunan di Indonesia. Jurnal Ekonomi Kreatif, 1(1), 1-12.

Atmadja, H. T. (2003). Perlindungan Hak Cipta Musik atau Lagu di Indonesia. Jurnal Hukum Dan Pembangunan, 33(2), 282-299. http://doi.org/10.21143/jhp.vol33.no2.1 379

Aulia, M. Z. (2007). Perlindungan Hukum Ekspresi Kreatif Manusia: Telaah terhadap Perlindungan Hak Kekayaan Intelektual dan Ekspresi Budaya 
Tradisional. Jurnal Hukum Ius Quia Iustum, 14(3), 359-372.

Aulia, M. Z. (2015). Politik Hukum Pembentukan UU Paten di Indonesia: Industrialisasi, Liberalisasi, dan Harmonisasi. Jurnal Hukum Ius Quia Iustum, 22(2), 223-237. http://doi.org/10.20885/iustum.vol22.iss 2.art3

Damian, E. (2005). Hukum Hak Cipta. Bandung: Alumni.

Gautama, S. (1995). Segi-segi Hukum Hak Milik Intelektual. Bandung: Eresco.

Hapsari, F. T. (2012). Eksistensi Hak Moral dalam Hak Cipta di Indonesia. Masalah-Masalah Hukum, 41(3), 460 464.

http://doi.org/10.14710/mmh.41.3.2012. 460-464

Idris, I. (2007). Pemanfaatan Nilai Ekonomi Hak Cipta oleh Masyarakat Lokal. Inovatif, 2(4).

Kariodimedjo, D. W. (2010). Perlindungan Hak Cipta, Hak Terkait, dan Desain Industri. Mimbar Hukum, 22(2), 265282. http://doi.org/10.22146/jmh. 16222

Kurnianingrum, T. P. (2015). Materi Baru dalam Undang-Undang Nomor 28 Tahun 2014 tentang Hak Cipta. Negara Hukum, 6(1), 93-106.

Rama, A. (2015, November 24). Memaknai Kesejahteraan. Republika. Jakarta.

Riswandi, B. A. (2004). Politik Hukum Hak
Cipta: Meletakkan Kepentingan Nasional untuk Tujuan Global. Jurnal Hukum Ius Quia Iustum, 11(25), 74-82. http://doi.org/10.20885/iustum.vol11.iss 25.art6

Roisah, K. (2012). Prismatika Hukum sebagai Dasar Pembangunan Hukum di Indonesia Berdasarkan Pancasila (Kajian terhadap Hukum Kekayaan Intelektual. Masalah-Masalah Hukum, 41(4), 622-630. http://doi.org/10.14710/mmh.41.4.2012. 622-630

Sardjono, A. (2010). Hak Cipta Bukan Hanya Copyright. Urnal Hukum Dan Pembangunan, 40(2), 252-269. http://doi.org/10.21143/jhp.vol40.no2.2 17.

Soelistyo, H. (2011). Hak Cipta Tanpa Hak Moral. Jakarta: Rajawali Press.

Stern, S. (2012). From Author's Right to Property Right. The University of Toronto Law Journal, 62(1), 29-91.

Sulistyawan, A. Y. (2019). Urgensi Harmonisasi Hukum Nasional terhadap Perkembangan Hukum Global Akibat Globalisasi. Jurnal Hukum Progresif, $7(2)$, 171-181. http://doi.org/10.14710/hp.7.2.171-181

Sutrisno, N. (1999). Implementasi Persetujuan TRIPs dalam UndangUndang Hak Cipta Indonesia. Jurnal Hukum Ius Quia Iustum, 6(12), 46-54. http://doi.org/10.20885/iustum.vol6.iss1 2.art4. 